\title{
School Mentors' Assessment of Science Student Teachers during Teaching Practicum
}

\author{
Thomas D.T. Sedumedi \\ Fhatuwani J. Mundalamo \\ Department of Mathematics, Science and Technology Education, \\ Tshwane University of Technology, Pretoria, South Africa \\ sedumeditdt@tut.ac.za; mundalamofj@tut.ac.za
}

\section{Doi:10.5901/mjss.2014.v5n20p1511}

\section{Abstract}

This study focuses on the process of mentoring, in particular the mentoring on subject matter knowledge during teaching practicum. Although student teachers were expected to teach during teaching practicum, we still consider such teaching as a learning process where well-equipped subject specialists such as schoolteachers are mentors. The assessment of teaching practicum at schools plays a major role in shaping a student teacher. It is therefore important to know both who assesses student teachers when they are learning in schools and what it is the assessors are assessing. Assessors of teaching practicum at schools are usually the university teacher educators. In this study, we investigated how mentors scored the student teachers against an instrument, their comments, and the value of such scores and comments in a student teacher's development. The average student teacher as judged by mentors performed well in all the variables assessed. These were divided into three categories, namely teaching strategies (79.6\%) subject matter knowledge or mastery of learning content (78.2\%); and classroom interaction or communication and learner involvement (75.6\%). Although the mentors' comments per item ranged in frequency from $6.4 \%$ to $56.0 \%$, the pattern was the same as for marks allocated. Mentors focused more on assessing teaching strategies (56.0\%), followed by praise of the student teacher (29.6\%). As in the case of marks allocated, subject matter knowledge (8.0\%) and classroom interaction (6.4\%) were scored very low.

Keywords: assessment; teaching practicum; assessor; mentor; and university

\section{Introduction}

Today the lingering challenge in most education systems is that of ensuring quality in both teaching and learning. However, the complex nature of both these processes makes the quest for quality difficult and in some instances close to impossible. An array of factors contributes to the difficulty. Human and physical resources are two common and most evident sources of the problems besieging educational processes. In this study, our attention is on the human resource aspect in education and specifically on teacher knowledge. At the centre of the complexity of the quality challenge in teaching and learning is the teacher's practical knowledge.

In this study we limited referring to pedagogical content knowledge for knowledge possessed by mentors or experienced teachers; instead we opted to refer to their knowledge as practical knowledge. According to Van Driel, Beijaard and Verloop (2001), this knowledge "consists of teachers' knowledge and beliefs about their own teaching practice and is mainly the result of their teaching experience" (p.138). It is primarily from this knowledge base that their mentorship will draw its strength. In fact, Van Velzen, Volman, Brekelmans and White (2012) posit that this knowledge is a product of "multiple modes of learning" which is used and diversified in practice.

In light of the type of practical knowledge that mentors possess, it is understood that their pedagogical content knowledge (PCK) which, according to Smith and Neale (1989), includes the knowledge of assessment (or knowledge of student errors), will differ and affect their mentoring activities accordingly. For example in schools teachers or mentors are expected to deliver quality knowledge to their students and in the case of this study to student teachers who come for teaching practicum. The knowledge they deliver will probably be a reflection of their practical knowledge and specifically their subject matter knowledge (which is a component of their PCK). This might not be easily met if the same teachers do not have the necessary skills to deliver the subject matter knowledge to students.

During the process of conducting student teachers' teaching practicum, the student teachers are expected to be assessed on how they teach a particular subject. This learning process involves an assessor who will observe and thereafter provide feedback on the quality of the lesson. Such feedback to student teachers (Smith and Lev-Ari, 2005) is 
said to be "a highly appreciated component of professional development" (p.300). University teacher educators, school teachers who take the role of mentoring student teachers during teaching practicum, and student teachers themselves (peers) are some of the individuals who assess student teachers during teaching practicum. As reported by Brooker, Muller, Mylonas and Hansford (1998), significant assessment practices and procedures have been under-explored.

In this study, we assessed mentors who were simultaneously the assessors of teaching practicum. We argue that this mentor-assessor mode of teaching practicum activity is not desirable (Le Maistre, Boudreau \& Paré, 2006) as the schoolteacher's roles are compromised and may blur his/her purpose or objectivity and affect the quality of both processes. Expectation of a mentor teacher's feedback is that it should be valuable to the development of a student teacher. Such an expectation is guided by the fact that mentors in schools spend ample time with the student teachers in mentoring them about how to teach a subject. This is not the case with the university teacher educator who only visits for a short time. In fact, Bailey, Scantlebury and Johnson (1999) indicate that student teachers regard their mentor teachers as most influential "upon their later teaching style" (p.162). Our assessment was therefore designed to establish, under these circumstances, the processes and outcomes of mentoring and specifically the mentoring on subject matter knowledge during teaching practicum.

\section{Research Questions}

In order to understand the assessment of a student teacher by a mentor, we answered the following questions:

\subsection{What are school mentors' foci of assessment when assessing lessons during teaching practicum?}

The aim with this question was to establish school mentors' foci and preferences regarding their assessment. Although our aim with this question may be considered irrelevant in the presence of criteria, assessors are sometimes biased by their practical knowledge in their assessment practices. In addition to their teaching skills, the outcomes of this question will also indicate different items (e.g. subject matter knowledge) assessed by the mentor during a lesson. Furthermore, the question serves to unearth what mentors consider valuable when assessing the student teacher's lesson.

\subsection{How would mentors' assessment practices of student teachers' lessons have affected their learning during teaching practicum?}

Assessment in teaching and learning generally has two main purposes. Firstly, it is meant to establish the extent to which the student (learner) has learnt the prescribed learning material. The second purpose is to enhance current and future learning by remedying the student's weaknesses in their knowledge bases or teaching skills. This remedying of students' knowledge is generally referred to as feedback. Feedback constitutes the main part of assessment for learning (AFL). This question was answered by looking at how all the mentors of the cohort of student teachers awarded marks and provided qualitative feedback.

\section{Literature Review}

A mentor is an experienced teacher who is there to support student teachers when they start their first phase of the teaching profession (Ulvik \& Sunde, 2013). Although the major role of mentors is to supervise student teachers in teaching practicum (Nyaumwe \& Mavhunga, 2005), in most cases they assess student teachers (Patrick, 2013). Student teachers are expected to reflect the knowledge acquired from university courses during their teaching practicum (OrlandBarak, 2002; Maphosa \& Ndamba, 2012). Such knowledge should include pedagogical knowledge as well as content knowledge (subject matter knowledge). The role of assessment of teaching practicum (Smith, 2007) is "to present the student teachers with feedback and guidance to enhance reflection and improve the student teachers' practice" (p.282). Kwan and Lopez-Real's (2005) study focused on investigating how mentors perceived their roles during the mentoring process and how those perceptions changed over the time of mentoring. Student teachers have high expectations of their teaching performance (Murray-Harvey, Slee, Lawson, Silins, Banfield \& Russell, 2000) during teaching practicum. Assessment of teaching practicum also serves the role of gatekeeping or controlling of access into the teaching profession (Orland-Barak, 2002). Mentors are gatekeepers who play an important role in making sure that student teachers understand the work of teaching (Butler \& Cuenca, 2012; Patrick, 2013). If student teachers are not assessed during teaching practicum, they would not know which areas of their teaching needed improvement. Although Butler and Cuenca see mentors as instructional coaches who "observe and evaluate instructional practice and provide constructive 
feedback aimed at improving the methods and techniques" (p.299) of student teachers, Ulvik and Sunde (2013) as well as Dunne and Dunne cited in Koç (2012) suggest that mentors' lack of training affects their mentoring. Mentors should be able to articulate pedagogical knowledge if they expect to assess student teachers well. This pedagogical knowledge should be characterised by practices such as "planning, timetabling lessons, preparation, teaching strategies, content knowledge, problem solving, questioning, classroom management, implementation, assessment and viewpoints for teaching" (Hudson, 2013, p.1). Zindi cited in Nyaumwe and Mtetwa (2006) indicates that reliance on one type of assessor (i.e. mentor or university teacher educator) to assess a student teacher during teaching practicum is "not valid because several assessors produce more objective assessments of student teachers' professional competencies than a single source" (p.36). In this study, the student teachers were assessed by peers, university teacher educators as well as mentors. We were interested in investigating the assessment process as conducted by a mentor. We are aware that Smith's (2007) model seeks to empower both the university teacher educators, mentors and school-based teacher educators (mentors); however, before the mentors can be empowered there needs to be some investigation on how and what they assess. Smith (2007) further indicates that predescribed criteria for student teachers' assessment during teaching practicum are insufficient. In the present study, such predescribed criteria were outlined in a teaching practice journal.

According to Smith (2007), mentors that are based in schools are in most cases faced with conflict "between their roles as supporters and critical friends and their roles as assessors, especially in relation to summative assessment" (p.283). Smith points out the importance of the school-based mentor's assessment and says that this should form the foundation for any other type of assessment. Mentor teachers interviewed in the study by Le Maistre et al. (2006) disliked engaging in summative evaluation processes. Although mentors can award a score in relation to the performance of a student teacher, Orland-Barak (2002) warns that high achievement in teaching practicum is not a predictor of future good teaching. Mentors, like any other assessors are expected to award a score. Since the mentor nurtures and supports the student teacher, there can be some tension when the time comes to evaluate (Le Maistre et al., 2006). Le Maistre et al. (2006) recommend that the role of mentors and evaluators should be separated, and that mentors should handle formative assessment and not summative assessment. Mentors should be viewed as "equal partners" who work with student teachers and should not be considered as just mere observers of what student teachers do during teaching practicum (Kwan \& Lopez-Real, 2005). In the present study, the mentor's assessment formed a foundation because in most cases it was conducted before the university teacher educator's assessment. School teachers who are mentors might mislead the student teachers (Sinclair, Munns \& Woodward, 2005) by asking them to forget what is taught to them in the university "as the 'real learning' occurs in the workplace" ( $p .210)$. Such advice from the mentors might affect the performance of student teachers when university teacher educators who use instruments designed in the university assess them. Many student teachers tend to replicate how their school mentors teach and this leads to student teachers not critiquing the mentor (Sinclair, Munns \& Woodward, 2005). This might lead to a student teacher's class looking exactly like that of the mentor teacher. A mentor teacher would definitely award a higher mark if the student teacher copied him/her and there might be very little critique of the student teacher's work. Darling-Hammond and Snyder cited in Tang (2008) suggest that multiple sources of evidence of student teachers' performances collected over time and in different contexts constitute a broad base in the assessment of teaching. In this study, however, the mentor teachers assessed student teachers in class for a period that ranged from 30 to 60 minutes.

\section{Methodology}

\subsection{Context}

This study was conducted at a South African university of technology. The study's focus is on teaching practice assessment of second-year Bachelor of Education (Science Education) students by their school mentors at their respective schools. Although most of the students who graduate with this four-year full-time qualification teach in South Africa, this qualification also prepares students to teach elsewhere in the world. The teaching practice for second-year students takes place at schools where the mentor teachers are located and lasts for a period of five weeks. During this period, each student teacher is allocated a mentor teacher who in most cases is a subject specialist who teaches the subject that the student teacher is mentored on. The mentor assists with the development of the student teacher's pedagogical content knowledge skills and the assessment thereof. The mentor teacher assesses one of the classes taught by the student teacher at a school. The other two assessments are done by a peer who is also a student teacher (Mundalamo \& Sedumedi, 2013) and a university educator (Sedumedi \& Mundalamo, 2012). Each assessor records all the assessment outcomes, including the marks, in a teaching practice journal. The student teacher keeps the journal for 
the duration of the teaching practice. At the end of a five-week teaching practice period, a student teacher submits the teaching practice journal to a university educator who is responsible for the theory of teaching Physical Science. This university educator then summarises all assessments and adds all the necessary marks to arrive at a percentage mark for the entire teaching practice session of that particular academic year. This study focuses on the assessment of student teachers by their school mentors.

\subsection{Research Design}

The design of this study was both quantitative and qualitative. The quantitative part consisted of the student teachers' scores on their teaching skills as assessed by their mentors and frequencies of codes designed from mentors' comments about the student teachers' teaching. The scores were awarded by mentors "as reflecting or quantifying the value of teaching capability" (Mundalamo \& Sedumedi, 2013, p.200) of the student teacher.

The qualitative part shows information from mentors about how they viewed the student teachers' teaching knowledge and skills. Qualitative judgements and scoring focused on the following variables emanating from the teaching practice journal: mastery of learning content (MLC), didactic flexibility (DF), communication and learner involvement (CLI), actualisation of content (AC), strategies, methods and techniques (SMT), and teaching media usage (TMU).

\subsection{Data Collection and Analysis Processes}

Data emanated from fifty-three (53) teaching practice journals. Qualitative (mentors' comments) and quantitative (allocated marks and frequencies of mentors' comments) data were collected from each of the six variables indicated under Research Design. Figure 1 below summarises the path followed from journal sampling to analysis and discussion of results.

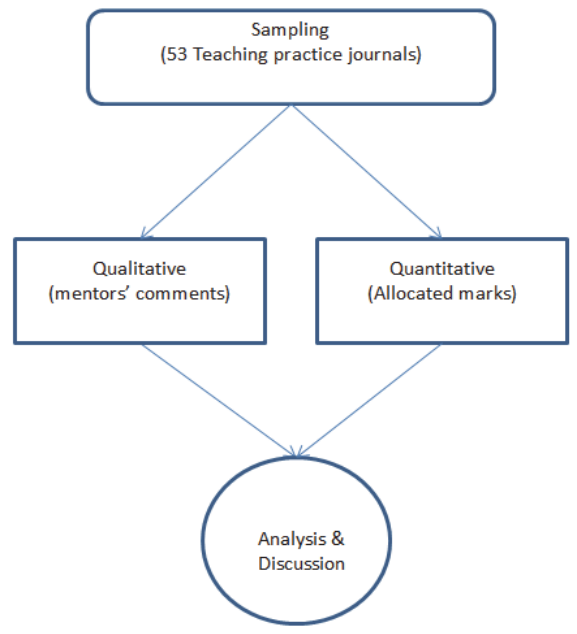

Figure 1: Data collection, analysis and discussion process

\subsection{Data Analysis}

Mentors' written accounts about student teachers' teaching performance were read from teaching practice journals and typed using Microsoft Word software. The mentors were assigned pseudonyms, i.e. M1, M2, M3, until M53. Each mentor's account on the student teacher activities was recorded under his/ her pseudonym.

This data were then read in order to generate the codes. The codes that emanated were classified under four major categories or themes. These categories are subject matter knowledge, teaching strategies, classroom interaction, and student teacher praise and appearance. Table 2 represents student teachers' performance as represented by codes under the four teaching categories. Subject matter knowledge and classroom interaction had only one code each, and 
these codes were subject matter knowledge (SMK) and classroom management (CM) respectively. Codes were generated from the mentor's accounts of the student teachers' teaching strategies. The codes were: introduction (INT), linking topics or lessons (LTL), lesson presentation (LP), time management (TM), learner knowledge (LK), teaching strategies (TS), syllabus/ curriculum (SC), media usage (MU), voice level (VL), lesson plan (LPN), and assessment (AS).The Student teacher praise and appearance category was represented by two codes, namely student teacher appearance (STA), and praise of student teacher (PST).

Mentors' comments under the same code were grouped together under that code in order to determine individual mentors' frequency per code along with total mentor group code frequency. In order to verify the correct frequencies for each item and for each teacher, we prepared a Microsoft Excel spreadsheet of codes versus mentors (with mentors on the $y$-axis and codes on the $x$-axis). This enabled us to represent frequencies for each item per code, and determine total frequency per mentor, and total frequency per item. We then compared Table 1 with the spreadsheet, and where there were discrepancies, we re-read all the mentors' comments to determine the correct frequencies.

\section{Findings and Discussions}

We have categorised the findings of this study according to the two research questions as follows:

\subsection{What are school mentors' foci of assessment when assessing lessons during teaching practicum?}

This question was answered by looking at the comments made by the mentors as they assessed the student teachers in class. Quantitative and qualitative assessment of student teachers' work assists in finding out what the mentors mostly focused on when they assessed during teaching practicum.

The mentors' comments about student teachers' teaching are described by codes in four categories (see Table 1 and Figure 2 below). The average percentage frequency of codes per category indicates a strong dominance of student teachers' teaching strategies (56\%). Student teacher praise is an item that is not reflected in the section where mentors award marks and it received the second highest frequency at 29.6\%. Subject matter knowledge and classroom interaction had frequencies of $8.0 \%$ and $6.4 \%$ respectively.

Table 1: Percentage frequency of the whole student teacher assessed as judged from mentors' comments during lesson observation

\begin{tabular}{|c|c|c|c|c|}
\hline & $\begin{array}{l}\text { Items reflected by school } \\
\text { mentor }\end{array}$ & $\begin{array}{l}\text { Frequency } \\
(\mathrm{N}=53)\end{array}$ & $\begin{array}{l}\text { Individual percentage } \\
\text { frequency }(\mathrm{N}=53)\end{array}$ & $\begin{array}{c}\text { Category's average } \\
\text { percentage frequency }(\mathrm{N}=53)\end{array}$ \\
\hline \multirow[t]{6}{*}{ Subject matter knowledge } & Subject matter knowledge & 14 & 26 & 8.0 \\
\hline & Introduction & 4 & 8 & \\
\hline & Linking topics or lessons & 7 & 13 & \\
\hline & Lesson presentation & 1 & 2 & \\
\hline & Time management & 4 & 8 & \\
\hline & Learner knowledge & 30 & 57 & \\
\hline \multirow[t]{6}{*}{ Teaching strategies } & Teaching strategies & 28 & 53 & 56.0 \\
\hline & Syllabus/ Curriculum & 6 & 11 & \\
\hline & Media usage & 2 & 4 & \\
\hline & Voice level & 4 & 8 & \\
\hline & Lesson plan & 8 & 15 & \\
\hline & Assessment & 1 & 2 & \\
\hline Classroom interaction & Classroom management & 9 & 21 & 6.4 \\
\hline \multirow{2}{*}{$\begin{array}{l}\text { Student teacher praise and } \\
\text { appearance }\end{array}$} & Student teacher appearance & 3 & 7 & 29.6 \\
\hline & Praising student teacher & 47 & 89 & \\
\hline
\end{tabular}

As in the case of marks awarded by mentors (see Table 2), percentage frequencies of mentors' comments reflect that the foci of mentors' assessment are firstly, teaching strategies, secondly, student teacher praising, thirdly, subject matter knowledge, and lastly, classroom interaction. 


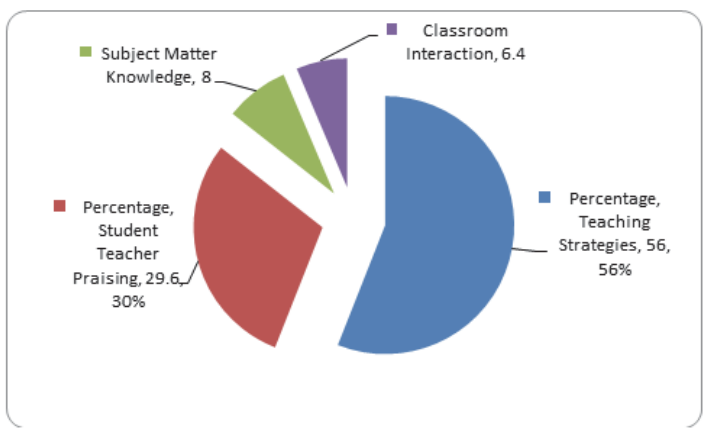

Figure 2: Frequencies of mentors' comments during observation of student teachers' lessons

The above results indicate that mentors focus on three knowledge areas, i.e. teaching strategies, subject matter knowledge, and classroom interaction, both through mark allocation and comments during observation of student teachers' lessons. However, a fourth item, student teacher praise, which only appears from comments provided by mentors, ranks second behind teaching strategies.

Table 2 below indicates how the mentors scored an average student teacher in items that appeared in the assessment instrument.

From Table 2, there is no significant difference among variables for an average student teacher as judged by a mentor (i.e. variables range from $75.6 \%$ to $80.7 \%$ ). This therefore shows that an average mentor judged an average student teacher as performing exceptionally well (above 75\%) in all six variables. However, if these items are ranked from highest to lowest average percentage allocation, then they can be arranged as follows: 1. Teaching media usage (80.7), 2. Actualization of content $(80.0 \%)$, 3. Didactic flexibility $(79.9 \%)$, 4. Mastery of learning content $(78.2 \%)$, 5. Strategies, methods and techniques (77.6\%), and 6. Communication and learner involvement (75.6\%)

Table 2: Student teachers' scores during the teaching practicum assessment by mentor teachers

\begin{tabular}{lcccccc}
\hline & $\begin{array}{c}\text { Mastery of } \\
\text { learning content } \\
(\mathbf{9}\end{array}$ & $\begin{array}{c}\text { Actualization } \\
\text { of content } \\
\text { (5) }\end{array}$ & $\begin{array}{c}\text { Didactic } \\
\text { flexibility } \\
(\mathbf{6})\end{array}$ & $\begin{array}{c}\text { Strategies, } \\
\text { methods and } \\
\text { techniques (5) }\end{array}$ & $\begin{array}{c}\text { Communication } \\
\text { and learner } \\
\text { involvement (7) }\end{array}$ & $\begin{array}{c}\text { Teaching } \\
\text { media usage } \\
(6)\end{array}$ \\
\hline Average mark allocated & 7.04 & 4.00 & 4.80 & 3.88 & 5.29 & 4.84 \\
Standard deviation & 1.17 & 0.72 & 0.79 & 0.71 & 1.24 & 0.92 \\
Average\% allocation & 78.2 & 80.0 & 79.9 & 77.6 & 75.6 & 80.7 \\
\hline
\end{tabular}

From Table 2 above, teaching media usage, actualization of content, didactic flexibility, and strategies, methods and techniques are combined to form Teaching Strategies (TS) with an average percentage mark of $79.6 \%$. These developments are reflected in Table 3 below.

Table 3: Marks allocated by mentors during observation of student teachers' lesson presentations

\begin{tabular}{l|llcc}
\hline & \multicolumn{1}{|c}{ Item } & Mark allocated (\%) & Average mark (\%) \\
\hline & 1. & Teaching media usage & 80.7 & \\
Teaching Strategies (TS) & 2. Actualization of content & 80.0 & 79.6 \\
& 3. Didactic flexibility & 79.9 & \\
& 4. & Strategies, methods and techniques & 77.6 & 78.2 \\
\hline SMK & 5. & Mastery of learning content & 78.2 & 75.6 \\
\hline Classroom interaction (CI) & 6. & Communication and learner involvement & 75.6 & \\
\hline
\end{tabular}

The percentage marks awarded by mentors to student teachers as reflected in Table 3 and Figure 3 show that the foci of mentors during assessment of student teachers lessons are firstly, teaching strategies (79.6\%), secondly, subject matter knowledge (78.2\%)of student teachers, and lastly classroom interaction (75.6\%). Teaching strategies contribute $34.1 \%$ of 
the 'total teaching knowledge' assessed by mentors, while subject matter knowledge and classroom intearaction contribute $33.5 \%$ and $32.4 \%$ respectively. The differences between the assessed knowledge are small, which is why it is important to find out how mentors commented during the assessment of the student teachers' lessons.

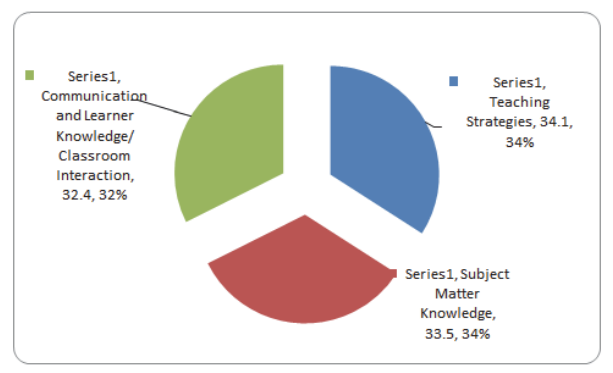

Figure 3: Contribution of classroom interaction, subject matter knowledge, and teaching strategies to whole student teacher pedagogical content knowledge

\subsection{Teaching Strategies (TS)}

Mentors' comments on how the student teachers taught the lessons consisted of eleven items, i.e. teaching strategies (TS), learner knowledge (LK), linking topics or lessons (LTL), lesson plan (LPN), syllabus/ curriculum (SC), time management (TM), voice level (VL), introduction (INT), lesson presentation (LP), media usage (MU), and assessment (AS). We discuss each of these items below.

\subsubsection{Teaching strategies (TS)}

Most of the mentors' comments related to the style of teaching. How the student teachers treated question and answer discussions in class was commented about by the mentors. For example, mentor M1 says "question and answers was good". Mentors like M6 and M26 also indicated that different teaching strategies should be utilized instead of using just one method. M6 advised a student teacher to "stop using narrative method continuously", while M26 said the student teacher needed "to improve on usage of different teaching methods". Other comments included those indicating that the student teacher presented the lesson well.

\subsubsection{Learner knowledge (LK)}

Most of the mentors' comments assumed that the student teachers interacted with their learners for a long time. A student teacher might be in a good position to "try to dig information from learners continuously to see if they follow" what is presented as suggested by M1, if he/she spent enough time to know them. For instance M1 continues to say "some learners lose interest while you are busy telling". This might be an indication that the student teacher does not have the knowledge of students in his/her class. Some student teachers might acquire knowledge of their students more quickly than others might probably because the environmental factors have some effect. Mentors' comments like that of M8 who says "he involves the learners and gives them enough work" shows that the student teacher knows his students. Mentors provided important comments revealing weaknesses and strengths that student teachers should consider for improving their teaching practice.

\subsubsection{Linking topics or lessons (LTL)}

All the mentors' comments indicated the importance of linking the previous lessons or prior knowledge with the present lesson. They indicated that it was important to have such linkage of knowledge at the beginning of the lesson. Their comments could be represented by M21's comment that "she needs to link her lesson with previous lessons". 


\subsubsection{Lesson plan (LPN)}

The mentors were aware of the importance of the lesson plan and its relationship to the lesson presented by a student teacher. After observing the student teacher's lesson, mentor M13 related the observed with the planned lesson. According to M13, the lesson observed represented well what was in the lesson plan or vice versa: "The lesson plan reflected everything that was to be done." A number of the comments can be summarised by that of M20: "His lesson planning and presentation are up to standard".

\subsubsection{Syllabus/ Curriculum (SC)}

The analysis shows the importance of school-based teachers as mentors of student teachers because they indicate whether the lesson presented was in line with the requirements of the school curriculum. A very good lesson by a student teacher would be irrelevant if it did not relate to the curriculum requirements. Thus, M2 advised a student teacher to "focus on the prescribed content". A student educator who failed to obey such advice would not be able to 'do' all the outcomes as achieved in a lesson observed by M14, who later indicated that the "educator [had] clearly done all the outcomes".

\subsubsection{Time management (TM)}

Three mentors, M2, M3 and M20, indicated the importance of time management, especially if the lesson was taught according to the lesson plans. M48 indicated that the lesson was presented within the time limits.

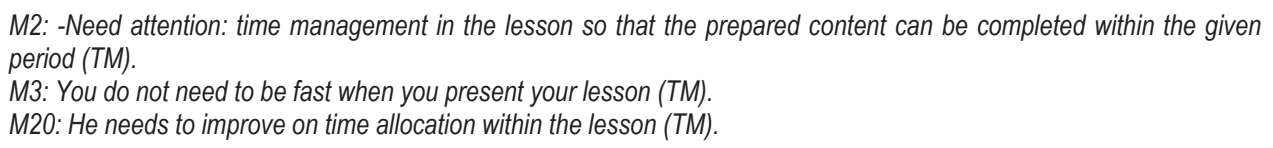

\subsubsection{Voice level (VL), Introduction (INT)}

The mentors (four of them) who commented about the student teacher's voice level said the quality of the voice or voice projection was good enough to be heard by students. They also found the introduction of the lessons by the student teachers to be good. M25 said, "...the topic was well introduced" while M14 and M48 said the "introduction was good". Only M48 commented on how the lesson was presented and said: "The lesson was well presented."

\subsubsection{Lesson presentation (LP), Media usage (MU), and Assessment (AS)}

It seems that the mentors did not see or value the importance of media usage during student teaching. Only two mentors commented and said that the teacher "uses some charts where necessary" and that "the student teacher also needs to bring more teaching media into the classroom in order to enhance teaching and learning". M45 is the only mentor who commented about assessment and the comment was as follows: "Try to give learners class work or home works after your lesson."

\subsection{Mentors Praising Student Teachers (PST)}

\subsubsection{Praising student teachers (PST)}

Thirty-one mentors praised the student teachers they observed and most of the comments were positive. Their comments could be easily summarised by M4's comment: "Well done. Your presentation was very good." Only one mentor, M5, indicated the weaknesses of a student teacher's lesson and reflected on an area to be improved. His/her comment was "Good presentation (PST) but problem with pronunciation."

\subsubsection{Student teacher appearance (STA)}

Only three mentors, namely M8, M12 and M49, praised three student teachers in terms of their outward appearance. The 
section of the instrument that is intended for mark allocation has some space to indicate if the student teacher was well groomed. Thus, after awarding marks for each of the student teachers' appearance the three mentors commented as follows:

M8: "... and always neat" (STA)

M12: "The educator presents himself [well] in front of the learners" (STA).

M49: "Good dress code" (STA).

\subsection{Subject Matter Knowledge (SMK)}

Only ten mentors out of fifty-three commented about the student teachers' subject matter knowledge of the subjects they taught while being observed. One mentor, M48, commented on a specific area of a mathematics lesson and said: "Explain where is ( $\mathrm{x}$ ) used and for what. BODMUS rule - define terms denominator, numerator." The other nine mentors' comments only indicated that the student teachers understood the content of the subject/ topic they taught. Some of their comments were as follows:

M7: "the educator is well grounded in the knowledge and content of the subject (SMK). He clearly explains the concepts" (SMK).

M13: "The educator shows good content knowledge (SMK). The concepts were dealt with very well" (SMK). ...and he is the master of the subject" (SMK).

M18: "he is trying and I really appreciate his mastery of learning content" (SMK).

M27: "You concretize your examples very well" (SMK).

\subsection{Classroom Interaction (Cl)}

Seven mentors provided comments on how student teachers managed the classroom environment. Mentors M1, M15 and M32 reported that the two student teachers they observed managed classroom interaction well. Their comments were as follows: M1: "Very good class control" (CM); M15: "Generally, she handled classroom management and control very well" (CM); M32: "Class well managed" (CM).

Mentors M2, M7, M22, M24 and M38 indicated that the student teachers were still lacking in terms of some skills needed for good classroom interactions. Their comments are indicated in the excerpts below.

M2: "Could create a good learning and teaching atmosphere" (CM)

M7: ... and discipline" (CM).

M22: "She is good in her class but there are some problems she [faces] like controlling the class (CM)....and she looked at the whole rows of the class" (CM).

M24: "Try your best to have an atmosphere, a good atmosphere and be able to have good point on how to motivate your learners to do your best" (CM).

M38: "You need to be developed how to discipline learners in your know behaviour" (CM).

- How would mentors' assessment practices of student teachers' lessons have affected their learning during teaching practicum?

The mentors' comments assisted student teachers to reflect on their teaching. When the student teachers presented the lessons well, the mentors provided comments that reflected that. There were also comments that indicated that student teachers should improve on certain aspects of their teaching, i.e. teaching strategies, learner knowledge, knowledge of curriculum and, to a lesser extent, how they should deliver specific subject matter to learners. Mentors' comments about the curriculum requirements were helpful for student teachers to relate the subject matter they taught to what was expected by the curriculum.

It is difficult for human beings to accept when someone points out that one has made mistake that needs to be corrected. We believe that student teachers' learning during observation by mentors improved immensely, especially realizing that most mentors praised student teachers they observed. Conversely, student teachers' topic-specific subject matter knowledge of teaching might not have improved since only one teacher out of 53 commented on the content taught.

\section{Conclusion}

We conclude that when mentors assess student teachers through awarding of marks during observation, the ranking in terms of awarding marks from highest to lowest are as follows: teaching strategies, subject matter knowledge, and lastly classroom interaction. However, when we conducted the content analysis of mentors' comments, we discovered that 
mentors still focused mostly on the assessment of teaching strategies, and praised student teachers more than they commented about their subject matter knowledge and classroom interaction.

We agree with Smith's (2007) assertion that pre-described criteria for student teacher assessment during teaching practicum may be insufficient considering the different contexts in which students engage in the practicum. In the present study, pre-described criteria were outlined in a teaching practice journal. We reported earlier that there was no section in the instrument that allowed mentors to praise students or what to praise them about. This could be the reason why 'praising student teachers' only appeared in mentors' written comments. However, we value all the comments provided by the mentors through the pre-described instrument in any form.

\section{References}

Bailey, B. L., Scantlebury, K. C., \& Johnson, E. M. (1999). Encouraging the beginning of equitable science teaching practice: Collaboration is the key. Journal of Science Teacher Education, 10(3), 159-173.

Brooker, R., Muller, R., Mylonas, A., \& Hansford, B. (1998). Improving the assessment of practice teaching: A criteria and standards framework. Assessment \& Evaluation in Higher Education, 23(1), 5-24.

Butler, B., \& Cuenca, M. (2012). Conceptualizing the roles of mentor teachers during student teaching. Action in Teacher Education, 34, 296-306.

Hudson, P. (2013). Strategies for mentoring pedagogical knowledge. Teachers and Teaching: Theory and Practice, 19(4), 363-381.

Koç, E. M. (2012). Idiographic roles of cooperating teachers as mentors in pre-service distance teacher education. Teaching and Teacher Education, 28, 818-826.

Kwan, T., \& Lopez-Real, F. (2005). Mentors' perceptions of their roles in mentoring student teachers. Asia-Pacific Journal of Teacher Education, 33(3), 275-287.

Le Maistre, C., Boudreau, S., \& Paré, A. (2006). Mentor or evaluator? Assisting and assessing newcomers to the professions. The Journal of Workplace Learning 18(6), 344-354.

Maphosa, R., \& Ndamba, G. T. (2012). Supervision and assessment of student teachers: A journey of discovery for mentors in Bulawayo, Zimbabwe. Journal of Emerging Trends in Educational Research and Policy Studies, 3(1), 76-82.

Mundalamo, F. J., \& Sedumedi, T. D. T. (2013). A mutual peer-to-peer assessment on pre-service teaching practicum. Journal of Social Sciences, 37(2), 197-208.

Murray-Harvey, R., Slee, P. T., Lawson, M. J., Silins, H., Banfield, G., \& Russell, A. (2000). Under stress: The concerns and coping strategies of teacher education students. European Journal of Teacher Education, 23(1), 19-35.

Nyaumwe, L. J., \& Mtetwa, D. K. (2006). Efficacy of college lecturer and student peer collaborative assessment of in-service Mathematics student teachers' teaching practicum instruction. The Mathematics Educator, 16(2), 35-42.

Nyaumwe, L. J., \& Mavhunga, F. Z. (2005). Why do mentors and lecturers assess mathematics and science student teachers on teaching practice differently? African Journal of Research in Mathematics, Science and Technology Education, 9(2), 135-146.

Orland-Barak, L. (2002). The impact of the assessment of practice teaching on beginning teaching: Learning to ask different questions. Teacher Education Quarterly, 29(2), 99-122.

Patrick, R. (2013). "Don't rock the boat": Conflicting mentor and pre-service teacher narratives of professional experience. Australian Educational Researcher, 40(2), 207-226.

Sedumedi, T. D. T., \& Mundalamo, F. J. (2012). Understanding field assessment of pre-service teachers on school practicum. Africa Education Review, 9(S1): S73-S90.

Sinclair, C., Munns, G., \& Woodward, H. (2005). Get real: Making problematic the pathway into the teaching profession. Asia-Pacific Journal of Teacher Education, 33(2), 209-222.

Smith, D. C., \& Neale, D. C. (1989). The construction of subject matter knowledge in primary science teaching. Teaching and Teacher Education, 5(1), 1-20.

Smith, K. (2007). Empowering school- and university-based teacher educators as assessors: A school-university cooperation. Educational Research and Evaluation, 13(3), 279-293.

Smith, K., \& Lev-Ari, L. (2005). The place of the practicum in pre-service teacher education: The voice of the students. Asia-Pacific Journal of Teacher Education, 33(3), 289-303.

Tang, S. Y. F. (2008). Issues in field experience assessment in teacher education in a standards-based context. Journal of Education for Teaching, 34(1), 17-32.

Ulvik, M., \& Sunde, E. (2013). The impact of mentor education: Does mentor education matter? Professional Development in Education, $39(5), 754-770$.

Van Driel, J. H., Beijaard, D., \& Verloop, N. (2001). Professional development and reform in science education: The role of teachers' practical knowledge. Journal of Research in Science Teaching, 38(2), 137-158.

Van Velzen, C., Volman, M., Brekelmans, M., \& White, S. (2012). Guided work-based learning: Sharing practical knowledge with student teachers. Teaching and Teacher Education, 28(2), 229-239. 